\title{
Institutional Change and the Social Sources of American Economic Empire: Beyond Stylised Facts
}

\author{
Leonard Seabrooke \\ Copenhagen Business School and The Australian National University
}

\begin{abstract}
The three volumes commented on here present some of the very best political economy and economic sociology scholarship on change within the US economy, as well as US-led changes in the international political economy. This review article seeks to identify the key contributions made by these works and how they improve our understanding of institutional change within the US economy. At a time when international relations and political science is populated by critiques of US empire, this article submits that understanding the 'economic taproot' of US power is essential in exposing its enduring character and weaknesses.
\end{abstract}

Gourevitch, P. A. and Shinn, J. J. (2005) Political Power and Corporate Control: The New Global Politics of Corporate Governance. Princeton NJ: Princeton University Press.

Sinclair, T. J. (2005) The New Masters of Capital: American Bond Rating Agencies and the Politics of Creditworthiness. Ithaca NY: Cornell University Press.

Whitford, J. (2005) The New Old Economy: Networks, Institutions, and the Organizational Transformation of American Manufacturing. Oxford: Oxford University Press.

The US 'Empire' looms over us all. Certainly one could be forgiven for having this impression when reading recent international relations scholarship. Discussions of how the Bush administration has abandoned international institutions and pursued a posture of aggressive unilateralism have dominated since $9 / 11$. For many scholars there has been a dramatic shift in foreign policy that has been augmented by neo-conservative forces within the US (Cox, 2003), of which the invasion of Iraq, the withdrawal from various international treaties, the abandonment of trade multilateralism and the propagation of ideas of a standard of civilisation all undermine the US's international legitimacy (Reus-Smit, 2004). Some scholars have welcomed the change in US foreign policy towards a more imperial character by arguing that a civilising mission, similar to the previous British imperial period, is one way to enhance world stability and economic development (Ferguson, 2003). Other scholars have reflected on the US's incapacity to maintain an empire due to its incoherence in producing a clear message on what it wants (Katzenstein, 2005; Mann, 2003). In addition to ideational muddling, the costs of empire are thought to be one reason why it may be unsustainable, leading to an 'Empire Lite' that will hurt both the international realm and US domestic society (Ignatieff, 2003). Still, as commented by Michael Cox in this issue, the most important aspect of US empire is that the US has the 
capacity to 'set the principal rules for those who live within the imperium and punish and reward in equal measure those who either disobey or play by these rules' (Cox, 2007, p. 5).

The aim for this review essay is to learn more about institutional change within the US economy, and what such lessons may suggest for the US's capacity to set the rules of the game for the world economy. One of the significant blind spots in much of the current literature is how changes in the US's behaviour in the international political economy may relate to changes at home, in a rerun of the false distinction between 'high' and 'low' politics. Of the arguments we do hear in the literature, the following views are common: (1) US government debt is now unsustainable, and the Japanese and Chinese governments may soon have the US over a barrel as they are the biggest investors in Treasury and other US federal agencies' bonds; (2) US capitalism is increasingly obsessed with short-term financial gains and, consequently, corporate scandals, typified by WorldCom and others; and (3) sharp increases in income inequality are creating perhaps irreparable social cleavages in the US (on these points, see, for example, Harvey, 2005, pp. 16-9, p. 157, p. 190). These are all sensible arguments. But the reply from students of US economy and society may be: (1) the Chinese and Japanese threat is minimal considering that the US's key role in the world economy is fulfilling the function not of international 'lender of the last resort' (Kindleberger, 1973), but of international 'consumer of the last resort', especially for Chinese exports; (2) US capital has much more intensive shareholder protection regulation than other states (Gourevitch and Shinn, 2005, reviewed below), and draws its capital from a much broader social base than is typically assumed (Seabrooke, 2006a); and (3) while there is substantial income inequality in the US, we must acknowledge that most Americans view this as socially legitimate (Glyn, 2006, p. 177), and even a driving force in the economy.

If the common themes that link US empire to change in the domestic economy can be so easily batted away, then we may require a better understanding of how changes in the US economy bear relation to changes in the international political economy. In this light, and as also noted by Michael Cox's contribution to this issue, we may learn from Susan Strange's $(1986 ; 1987 ; 1988)$ insights during the 1980s on how the US was able to extend its hegemony in the world economy through 'structural power', despite its apparently crumbling domestic economic system.

For Strange, the US created an empire based on finance that allowed it to establish the global rules of the game. In contrast to doomsayers of the time, who perceived US hegemony and material power to be in relative decline (Gilpin, 1987; Keohane, 1984), Strange argued that hegemony was being extended and strengthened by changing the preferences of other states and market actors in ways that favoured US interests. Within the US at the time there were problems of 'surplus capacity' in production, record levels of state and personal indebtedness and increasing problems with social dislocation. So while many political economists 
were predicting the demise of US hegemony and talking up the weaknesses of the US economy and its seemingly inevitable replacement by Japanese-style capitalism (providing a precursor to the 'Varieties of Capitalism' (VoC) debate [Hall and Soskice, 2001]), Strange identified a shift from state power to the market, providing the US with greater structural power in the international political economy (see also Helleiner, 1994; Seabrooke, 2001). Strange also stressed that to understand how the US could generate structural power in the international political economy, it was necessary to understand political and economic cooperation within the US (Strange, 1987, pp. 553-4). Suggested here is the view that students knew US power when they saw it in the international realm, but had a harder time explaining domestic changes within the US.

Indeed, akin to John A. Hobson's (1902) analysis of British imperialism, analysing change within the US may provide the means to understand better the 'economic taproot' of US imperialism (Seabrooke, 2004). This review considers the three excellent books listed above with this in mind. A word of caution is required. While the books focus on US-led changes, and they all discuss the US within a broader comparative or international context that allows us to discuss the economic social sources of US structural power, they are not explicitly directed at the US empire debate. However, this is all the better for the purposes of this review, since they are less inclined to present stylised facts about US economic weaknesses and more likely to produce counter-intuitive insights. The books are also of broader conceptual interest for political economy and economic sociology, especially in their understanding of how actors determine their preferences and interests, and the role of knowledge and ideas in creating institutional change (e.g. Blyth, 2002).

\section{The Decline of US Manufacturing?}

Let us begin with the book that we might expect to have the least relevance to the US empire debate. Josh Whitford's The New Old Economy: Networks, Institutions, and the Organizational Transformation of American Manufacturing is a carefully crafted and researched piece of scholarship based on exhaustive interviews with manufacturers in the American Upper Midwest. To my mind, the book presents a new benchmark in work that fuses organisational sociology and comparative political economy, primarily because it overturns common assumptions, both about how firms work in the US economy as well as what we may call the logic of the firm.

Whitford explains how globalisation has not simply led to the mass loss of jobs from American manufacturing (some three million between 2000 and 2003), nor to the complete outsourcing or offshoring of American productive capacity. While both of these processes have occurred to a large extent, examining the effects of globalisation on the US economy provides an opportunity to refute notions that there is one style of US capitalism. As such, rather than VoC, Whitford 
is among a range of scholars examining 'varieties in capitalism' (e.g. Berk and Schneiberg, 2005). In the US case there are especially good reasons for doing so, since ignoring sources of innovation leads us to become "far too pessimistic about the tools available for the construction of institutions to facilitate collaborative nonmarket coordination even in the ostensibly unfeasible American context' (Whitford, p. 48). Others have also acknowledged that while the VoC framework has great strength in parsimony, its binary separation of Liberal Market Economies (LMEs) and Coordinated Market Economies (CMEs) can exaggerate the relative weight of coordination and/or competition in each, providing a rosy picture of Germany (the CME) and a downcast picture of the US (the LME) (Blyth, 2003).

Whitford provides an important reminder that while the contemporary focus on the US is on finance, telecommunications, information technology and similar, international trade is predominantly in goods. The US goods trade deficit, after all, outweighs the US service trade surplus by a factor of 10:1 and, during the period of study, was growing faster than the growth in US services in the world economy (p. 12). Nevertheless, since 1979, when US manufacturing was at its post-war employment peak, 44 percent of jobs had been shed by 2004, reducing manufacturing as a proportion of the US workforce from 23 to 13 percent. Whitford convincingly demonstrates that it is a mistake to treat all deindustrialisation as of a piece, as to do so masks the degree to which it was also a process of de-unionisation, de-urbanisation and, particularly, of decentralisation (p. 1, p. 154). US manufacturing is a highly regional affair and as wages were reduced due to global economic pressures (as his interviewees testify), there is relocation to the extent that job losses were very concentrated in certain cities even as other regions gained jobs (p. 11, p. 87). So while in general there is a decline in wages during the period, and a strong perception of US manufacturing decline associated with the American automotive industry, there has in fact been enough heterogeneity in the process that simply to say 'industrial decline' is too facile.

The key pressure from globalisation is for firms to disintegrate vertically - that is, that as a consequence of increased global competition, technological advance and a more finicky and demanding customer public, Original Equipment Manufacturers (OEMs) seek to specialise in 'core competencies' so that they have a chance of staying ahead of the game (p. 17). OEMs then outsource, and create network ties with supplier firms, rather than attempting to keep all production in-house. Whitford examines this change to a 'new old economy', drawing from over a hundred interviews with 56 durable manufacturing firms with a range of products, including agricultural and construction equipment, metals and tool makers, non-automotive vehicles, medical equipment, plastics and others.

The most important element of the book is that the character of US manufacturing capitalism is somewhat different from what we may guess. Normally we would assume that firms engage in two kinds of relationships - either long-term collaborative relationships or arms-length competitive relationships. Whitford 
demonstrates that most relationships couple elements of collaboration and opportunism, of arms-length competition and deep interdependence (p. 27, p. 110) in seemingly contradictory, yet prevalent and stable, relationships. These are generated by, but also generate, substantial relational uncertainty. And they do give manufacturers the tools to respond quickly to market shocks and to technological advances. But they also leave the industry, and the supplier firms that Whitford shows to have become central to the sector's performance, to be vulnerable to requests for lower prices that reduce margins and thus sabotage their investment in worker training, $\mathrm{R} \& \mathrm{D}$ and capacity for innovation. This is not only a problem for US firms, but all suppliers in the international political economy (p. 119).

The New Old Economy draws on this finding to show that the heterogeneity and partial collaboration can enable the US government at federal, state and local levels to engage in modernisation and innovation processes in ways the $\mathrm{VoC}$ literature predicts to be institutionally proscribed. The Wisconsin Manufacturers' Development Consortium (WMDC), for example, is discussed as an association of private firms that has worked with the state for industrial modernisation (pp. 135-53). In contrast to how the US is commonly seen, there can be (and is) a role for government in fostering innovation. The US federal government's Manufacturing Extension Partnership (MEP), for example, was given a boost by the Clinton administration to provide partial funding for not-for-profit manufacturing modernisation centres, as long as state and local governments came to the party, and as long as private business played a coordinating role. This programme had its budget cut by the Bush administration before being reinstated following political outcry, within the context of industrial job losses, in 2005 (pp. 134-5). The capacity for positive state-market relationships is commonly attributed to CME states (e.g. Culpepper, 2003), and while it is assumed that US business is incapable of organising collectively, the problem is really getting different levels of government to coordinate effectively (Whitford, p. 153). This argument dovetails nicely with other new work on the more ordinary, everyday social sources of financial power in the US, such as through mortgage securitisation and state intervention for creditworthiness for the lower-middle classes (Seabrooke, 2006a). While the US undoubtedly has a dog-eat-dog economic system, it is also capable of helping old dogs learn new tricks.

It should be noted that Whitford provides a significant conceptual innovation for economic sociology and comparative political economy. In particular, Whitford weaves through social embeddedness networks literature, the VoC literature and also the 'neo-pragmatist' 'learning by monitoring' literature (Sabel, 1994). Whitford demonstrates that some US manufacturing firms are using 'neopragmatist' techniques to innovate and learn from other systems, so that rather than facing overwhelming uncertainty they embrace ambiguity as a creative force (pp. 29-30, p. 46; compare Best, 2005). If such pragmatist techniques exist - albeit in partial and fragmentary form - in the sector of the US economy written off 
since the 1980s, then we may pause for thought about the sources of US structural power in the early twenty-first century. Indeed, during the 1980s and 1990s Strange stressed how an important component of structural power was knowledge regimes, and in manufacturing Whitford stresses the extent of innovation (see also Stopford and Strange, 1991). He does not, by any means, discount the severe costs to labourers imposed by the restructuring of the last decades, nor the struggle faced by supplier firms who can have their profits undercut by aggressive OEMs able to leverage a far-flung network of global producers. In an environment where there is increasing emphasis on examining how global corporations establish benchmarks and learn from each other's different localised environments (Kristensen and Zeitlin, 2004), Whitford's work calls us not to write off US manufacturing in 'old' industries, but to see it as retaining a capacity to innovate in the world economy.

\section{The Diffusion of US-style Corporate Governance?}

Peter A. Gourevitch and James J. Shinn's Political Power and Corporate Control: The New Global Politics of Corporate Governance blends quantitative and qualitative comparative analysis to produce a formidable piece of research on why systems of corporate governance differ according to political compositions present within states. There is little doubt that the book will become something of a 'bible' for students of corporate strategy and political economy alike. It directly contributes to a growing literature on how multinational corporations' strategies and practices are overwhelmingly homespun (Doremus et al., 1999). Gourevitch and Shinn frame their analysis against the popular backdrop of corporate scandals, such as Enron, WorldCom, Vivendi, Parmalat and others. The fear here, of course, is that weak corporate governance leaves both shareholders and those with pension fund contributions managed by a corporation in deep trouble. What determines the extent of the trouble, for Gourevitch and Shinn, is largely driven by how political coalitions play out within the home state. The basic approach in the book will be of no surprise for students of political economy. After all, Gourevitch's Politics in Hard Times (1986) is a classic text in which he analysed how states responded differently to the Great Depression with the aim of producing a 'historical sociology of the trajectories of national responses to external changes' (Gourevitch, 1986, p. 221; compare Seabrooke, 2007b). The key figures in this earlier work were financiers, agrarian interests, labour and the organised political interests they represented. In Political Power and Corporate Control the key players are owners, managers and workers, and the political coalitions and interests they forge, or who represent them.

Given the focus on owners, managers and workers, the book concentrates on separating out shareholding rights and ownership concentrations in different national contexts. In a manner complementary to Daniel Verdier's (2002) excellent analysis of the relationship between state centralisation and stock market and banking systems, Gourevitch and Shinn discuss the historical development of 
corporate governance systems according to the number of 'veto players' within the political systems, with majoritarian systems exhibiting fewer points compared to consensus systems (p. 69, p. 71). The kind of politics, dependent on the context of the period, then determines the form of corporate governance within the country cases. In addition to the US, a diverse range of states are discussed, including China, France, Germany, Korea, the Netherlands and the UK, among others. The cases are explained by how the politics shapes the 'degrees of coordination', the rules that structure markets (including regulations on labour, pricing, anti-trust and supplier-distributor relations) and the extent of minority shareholder protections (MSPs) (p. 11). There is also a useful distinction between external investors who establish a board to monitor managers, and internal 'blockholders' who provide direct monitoring. The book provides a wealth of quantitative evidence which clarifies how states fit into this framework. Here the basic relationships are that workers will side with managers for employment protection, but will side with owners (and vice versa) when pension fund systems make them stakeholders in a company. Also, there is a close relationship between owner 'blockholders' and managers in more consensual systems, where workers are more likely to have a strong voice (p. 23).

For this review, the most important aspect of the book is the attention given to how the regulation of pension plans and financial institutions can explain changes to US corporate governance. To kick this story off Gourevitch and Shinn use the 'analytic narratives' framework associated with rational choice analysis (Bates et al., 1998) to trace key moments, such as in a punctuated equilibrium model, that have changed US corporate governance over the past century. The US case starts with blockholders, such as Rockefeller and Carnegie. In this sense nineteenth-century US corporate governance is not necessarily all that distant from Germany. However, oligarchs in the US case adopted a very thin form of MSP to protect their own interests during a period of merger and acquisitions activity (Gourevitch and Shinn, p. 243). The authors then follow moments of crisis at which the power of oligarchs was threatened and then reduced, to the benefit of MSP, from the Sherman Antitrust Act of 1890 to the creation of the US Securities and Exchange Commission (SEC) and the Glass-Steagall Act, which separated commercial and investment banking, in the mid-1930s, to the collapse of pension funds in the 1960s that spurred employee protection in the 1970s, and to the Democrat-led attack on the tax deductibility of pension contributions by firms with the Tax Equity and Fiscal Responsibility Act of 1982 (pp. 244-9).

The transition within the US pension system from defined benefits to defined contributions is hugely important for economic change within the US economy, and for change in the world economy more generally. As Paul Langley (forthcoming) clarifies, defined contribution 'schemes are invested on the behalf of workers by scheme trustees and the asset management industry, and the employer bears the risk that returns on investment may not be sufficient to meet guaranteed benefits'. In the US case this took place through the development of '401(k)s' in 
the 1980s that established a new logic for the individualisation of economic responsibility for both workers and the institutional investors they operate through. The change is also critical in reconfiguring relations between owners, managers and workers in the US case as shareholder value becomes important for workers, leading them to call for greater corporate transparency (in 1999 the US had $\$ 7$ trillion in pension assets of which 60 percent was in equities). This is a broader social change and, as Gourevitch and Shinn argue, the expansion of $401(\mathrm{k})$ schemes to provide future retirement income included 'groups not traditionally engaged in politics as investors' (p. 243, p. 249; see also Seabrooke, 2006a, pp. 133-6).

Given these shifts, senior managers reacted to how workers had sided with external owners by buying large blocks of shares (as much as 10 percent between 1990 and 2000) and, in doing so, distorting corporate strategies that led to the scandals of the late 1990s (Gourevitch and Shinn, pp. 251-3). Such actions were accompanied by financial deregulation of the same period. As the authors discuss, this situation led to intensive political pressure that crystallised in the SarbanesOxley Act of 2002, which provides more stringent evaluation and disclosure requirements on public companies, including prohibitions on inside trade during pension fund 'blackout' periods (p. 257).

There is no doubt that the trajectory of change discussed by Gourevitch and Shinn has had a global impact. And the impact is American in character. Indeed, one could be forgiven for thinking that Gourevitch and Shinn see high MSPs and low ownership concentration as positive (the US is first in both categories here [see p. 48, p. 53]). They do argue that rather than a 'race to the bottom' in corporate governance, there will be a 'race to the top' - while also realising that the US itself has experienced a range of corporations whose managers have relocated them to states with less comprehensive MSPs (pp. 288-9). One could also question here the extent to which the rationalist approach adopted by the authors favours the suggestion that workers, managers and owners are willing to take on board additional uncertainty for greater economic reward. Indeed, others have criticised the kind of punctuated equilibrium models that match policy change to political coalitions on the grounds that they are blind to how changing economic ideas and expectations about how the economy should work among broader society can prioritise certainty and provide unexpected constraints on politically powerful actors (Seabrooke, 2007a; 2007c).

\section{Do US Bond Rating Agencies Provide Informal Imperial Rule?}

Timothy J. Sinclair's The New Masters of Capital:American Bond Rating Agencies and the Politics of Creditworthiness is a carefully crafted investigation of these very important but understudied actors in the international financial order. Sinclair's book undoubtedly establishes him as the political economy scholar on rating agencies, and goes a long way to demonstrating complementarities among con- 
structivist and rationalist approaches. In particular, Sinclair is interested in learning from economic sociology to understand the creation of a market (p. 11).

Sinclair establishes how rating agencies have become an 'authoritative source of judgments' in the assessment of creditworthiness in domestic and international capital markets, and therefore wield considerable power and influence (p. 2). He traces the historical development of the key agencies in the US (most notably Standard and Poor's and Moody's), and illustrates the impact of agencies in a variety of public and private contexts, including their effect on sub-national governments, sovereign debt, corporations and international financial crises (see also Sinclair, 1994; Mosley, 2003).

For Sinclair US rating agencies are social actors that rely on the construction of intersubjective understandings to have an impact within the marketplace. They therefore seek to take market uncertainties and transform them into predictable risks. Sinclair draws a parallel between how rating agencies operate and John Maynard Keynes' story of how uncertainty reduction within financial markets is akin to a newspaper's beauty pageant competition. Here the winner was the reader who chose not the prettiest girl according to his or her own subjective preference, but the girls closest to what all other contestants chose, to conform with their intersubjective preferences (p. 52). Similarly, rating agencies are recipients of information within an uncertain intersubjective environment as well as creators of information that seek to mitigate uncertainties by putting forward a subjective understanding that claims to be superior to others. The trick here for agencies is to be viewed as endogenous to uncertainty mitigation under financial globalisation rather than exogenous to these processes. Achieving such endogeneity, however, requires that their information on ratings must be consistent over time to have credibility (p. 15, pp. 41-2).

Sinclair argues that a change in practices within US domestic and international financial markets has bolstered the role and importance of rating agencies. Of particular importance here are the US-led processes of disintermediation - where debt securities are replacing traditional bank loans - and securitisation - where capital from stable sources of income is channelled into the financing of debt securities (p. 3; see also Seabrooke, 2001; 2006a; 2007a). Both processes have encouraged US financial market actors to use shorter-term horizons and larger volumes of capital, and to rely more on rating agencies for judgements of creditworthiness rather than, as with traditional mediation, local trust and reputation. Fixed-income securities are the best case here for Sinclair, since changes to their value within the marketplace is driven by how they are rated (p. 86).

In drawing from international relations and economic sociology literatures, Sinclair formulates the notion of an 'Embedded Knowledge Network' (EKN) to clarify how rating agencies seek to achieve endogeneity within financial markets. In putting forward the concept of EKNs, Sinclair draws upon the epistemic communities literature to discuss how they provide new ways of rationalising a 
scenario (p. 14). As EKNs, rating agencies produce benchmarks around which other actors converge, therefore providing them with 'unconscious power' from the establishment of a 'mental framework of rating orthodoxy' rooted in the US context (p. 17). In particular, Sinclair is interested in understanding the mechanisms involved in a transition over time from a 'hegemony of social interest linked to growth and expansion' that has transformed into 'an interest more narrowly concerned with the reproduction and safeguarding of its wealth' (p. 87). By exposing this mental framework Sinclair seeks to stress that the ratings given by agencies are not natural but contestable claims (p. 50).

Sinclair's argument throughout the book is broken down into three aspects: investment, knowledge and governance. By focusing on these categories Sinclair is able to illuminate the connections between material incentives for investment, the construction of knowledge on creditworthiness and changing practices among those who are being rated or seek to be rated (pp. 18-20). This is especially the case given that creditworthiness is both a causal belief (i.e. the likelihood of repayment) and a principled belief (i.e. the obligation to repay) (pp. 65-6). These sub-arguments are also complemented by a skilful use of counterfactual analysis, which concedes ground to rationalist approaches as a default position only then to tear it away in demonstrating the power of knowledge used by rating agencies and therefore illustrating the relevance of a constructivist approach (p. 72).

The book runs through a number of case studies that demonstrate how US rating agencies have developed a framework for the rationalisation of creditworthiness assessment, how they typically impact on the fate of corporations, national and sub-national governments and sovereign debt. The book discusses the 'blown calls' in international financial crises in recent decades, as well as corporate scandals that have rocked the US (such as Enron). Through these cases Sinclair carefully works through the investment, knowledge and governance sub-arguments, aided with counterfactual analysis to demonstrate why the rating agencies' judgements matter unto themselves. He also carefully details how changes within the US have led to changes in private governance in the international political economy.

On US corporations, Sinclair demonstrates that without ratings downgrades GM would have kept on issuing debt securities in the early 1990s (p. 79). Similarly, Ford was on the end of the sting from rating agencies, which constructed a sense of crisis within the company (p. 80, p. 83). More generally, he demonstrates how powerful rating agencies are in changing political actors' perceptions of the importance of conforming with a norm of fiscal conservatism in order to reduce the cost of accessing capital markets for government operations (p. 101, pp. 111-3, pp. 140-1).

A key theme in the book is the relationship between rating agencies and the US political and economic environment. In particular, Sinclair discusses how the US SEC granted the major rating agencies the title of Nationally Recognized Statistical Ratings Organization. As such, they are increasingly integrated into US 
domestic regulation and international financial regulation as legitimate actors that potentially constitute a further extension of US structural power, in accordance with Strange's framework. Such status also leads rating agencies to act with great bravado, including the increasingly common practice of rating some firms without their prior consent (p. 30). Increasingly, then, this leads agencies to 'rule at a distance', in which 'social forces are self regulating within the norms of the system' (p. 67). Sinclair argues that 'Rating agencies did not invent these governance structures but act as interpreters, advocates, and enforcers of them around the world' (p. 20). At the same time, the agencies produce the 'universalization of self-regulating markets and the exoticization of other modes of social interaction' (p. 60), which suggests a more diffuse process of US hegemonic or imperial control.

\section{Conclusion}

The three books reviewed in this article all provide unique insights into institutional change in the US economy. Accordingly, they provide an important reminder that when discussing US empire we should not rely on stylised facts and sweeping conclusions concerning how the American economy is crumbling from the inside, but should instead turn to cutting-edge research that explores what is happening 'at the coalface'. In this way we can answer Susan Strange's call (1986) that understanding US structural power in the international political economy requires us to examine changes within its domestic political economy.

How do these books help us understand the 'economic taproot' of US empire? At first cut the books provide mainly positive news about change in the US economy - and good news is hardly associated with the debates about the Bush administration's turn to aggressive unilateralism. It is common to link regressive domestic economic changes to a negative turn in foreign economic policy. My own work has been in this vein, pointing out how the Bush administration's changes to taxation, credit and property policies are especially harmful to people on below median income (especially the poor) and undermine its social source of financial power, while at the same time the character of US influence abroad is more like the kind of rentier-style behaviour we associate with imperialism (Seabrooke, 2004; 2006a, pp. 206-13; 2007a). However, we need to look beyond the negative aspects of changes put in place by the Bush administration. The books reviewed here demonstrate that little can be taken for granted in the US case and that exploring contestation between groups about how the economy should work is particularly important for understanding domestic economic change. In this light, Whitford demonstrates the extent to which the decline of manufacturing must also be understood as a process of innovation and transformation that permits some US firms still to lead within their area in the world economy. Such innovation has been created through 'contradictory collaborative' relationships between firms that defy the assumed logic of either arms-length competition or close collaboration between firms. Gourevitch and Shinn 
demonstrate the extent to which there is ongoing contestation, especially during periods of crisis, among workers, owners and managers that now provides Americans with intensive MSPs and also increased scrutiny on corporate governance because of domestic political coalitions. As there is a diffusion of corporate governance from the US outwards, understanding how diffusion will not simply lead to isomorphism but will produce persistent variation due to domestic politics is important in understanding the limits of US imperial reach (compare Broome, 2006). Finally, Sinclair's book speaks volumes on how changes in creditworthiness assessment have produced new forms of mixed quasi-public governance (through bond rating) within the US economy that are transforming the world economy. As such, his work directly contributes to our understanding of the nature of US structural power in the world economy in the early twenty-first century.

Finally, the three books demonstrate important domestic and international effects that political economy scholars can only tackle with some help from economic sociology and organisational sociology (see also Campbell 2004). For example, Whitford demonstrates how incrementally changing expectations in the everyday life of firms is important for the national economy and US firms' engagement with the global economy. This is something quite different from studying institutional change, as Gourevitch and Shinn do, within what is essentially a punctuated equilibrium model of change. By understanding 'everyday' dynamics we may be more able to recognise that uncertainty and ambiguity can produce seemingly contradictory yet beneficial relationships, rather than focusing on uncertainty as a period of crisis in which political coalitions make a clear push for institutional change (compare Seabrooke 2006b; Hobson and Seabrooke [forthcoming]). Similarly, Sinclair helps us to understand how US power in the contemporary international political economy is being extended in more diffuse forms through the notion of an Embedded Knowledge Network. As such, both Whitford and Sinclair provide conceptual advances on the role of intersubjective understandings in generating institutional change (see also Sharman, 2006), while Gourevitch and Shinn acknowledge that understanding how 'People's preferences are mediated by the way they understand what is happening ... [requires] collaboration with sociologists' (p. 287). In sum, all three books make great strides in helping us better understand the relationship between US domestic institutional change and US influence in the world economy, and especially that our stylised facts about the weaknesses behind US empire require updating or at least questioning.

(Accepted: 22 September 2006)

\section{About the Author}

Leonard Seabrooke, Associate Professor in the International Center for Business and Politics, Copenhagen Business School, and Adjunct Senior Fellow, Department of International Relations, RSPAS, The Australian National University, Canberra, ACT 0200, Australia. email: ls.cbp@cbs.dk

\section{Note}

My special thanks go to André Broome for his feedback on earlier drafts of this article. My thanks also to John M. Hobson and Victoria Smith for their comments and for their patience. 


\section{References}

Bates, R. H., Greif, A., Levi, M., Rosenthal, J.-L. and Weingast, B. (1998) Analytic Narratives. Princeton NJ: Princeton University Press.

Berk, G. and Schneiberg, M. (2005) 'Varieties in Capitalism, Varieties of Association: Collaborative Learning in American Industry, 1900 to 1925', Politics E Society, 33 (1), 46-87.

Best, J. (2005) The Limits of Transparency: Ambiguity and the History of International Finance. Ithaca NY: Cornell University Press.

Blyth, M. (2002) Great Transformations: Economic Ideas and Institutional Change in the Twentieth Century. Cambridge: Cambridge University Press.

Blyth, M. (2003) 'Same as It Never Was? Typology and Temporality in the Varieties of Capitalism', Comparative European Politics, 1 (2), 215-25.

Broome, A. (2006) 'Civilizing Labor Markets:The World Bank in Central Asia', in B. Bowden and L. Seabrooke (eds), Global Standards of Market Civilization. London: Routledge/RIPE Series in Global Political Economy, pp. 119-30.

Campbell, J. L. (2004) Institutional Change and Globalization. Princeton NJ: Princeton University Press.

Cox, M. (2003) 'The Empire’s Back in Town: Or America's Imperial Temptation - Again', Millennium, 32 (1), $1-27$.

Cox, M. (2007) 'Still the American Empire', Political Studies Review, 5 (1), 5.

Culpepper, P. D. (2003) Creating Cooperation: How States Develop Human Capital in Europe. Ithaca NY: Cornell University Press.

Doremus, P. N., Keller, W. W., Pauly, L. W. and Reich, S. (1999) The Myth of the Global Corporation. Princeton NJ: Princeton University Press.

Ferguson, N. (2003) Empire: The Rise and Demise of the British World Order and the Lessons for Global Power. New York: Basic Books.

Gilpin, R. (1987) The Political Economy of International Relations. Princeton NJ: Princeton University Press.

Glyn, A. (2006) Capitalism Unleashed: Finance, Globalization, and Welfare. Oxford: Oxford University Press.

Gourevitch, P. A. (1986) Politics in Hard Times: Comparative Responses to International Economic Crises. Ithaca NY: Cornell University Press.

Hall, P. A. and Soskice, D. (eds) (2001) The Varieties of Capitalism: The Institutional Foundations of Comparative Advantage. Oxford: Oxford University Press.

Harvey, D. (2005) A Brief History of Neoliberalism. Oxford: Oxford University Press.

Helleiner, E. (1994) States and the Reemergence of Global Finance. Ithaca NY: Cornell University Press.

Hobson, J. A. (1902) Imperialism: A Study. London: George Allen and Unwin.

Hobson, J. M. and Seabrooke L. (eds) (forthcoming) Everyday Politics of the World Economy. Cambridge: Cambridge University Press.

Ignatieff, M. (2003) Empire Lite: Nation-Building in Bosnia, Kosovo and Afghanistan. London: Vintage.

Katzenstein, P. J. (2005) A World of Regions: Asia and Europe in the American Imperium. Ithaca NY: Cornell University Press.

Keohane, R. O. (1984) After Hegemony: Cooperation and Discord in the World Political Economy. Princeton NJ: Princeton University Press.

Kindleberger, C. P. (1973) The World in Depression, 1929-1939. London: Allen Lane.

Kristensen, P. H. and Zeitlin, J. (2004) Local Players in Global Games: The Strategic Constitution of a Multinational Corporation. Oxford: Oxford University Press.

Langley, P. (forthcoming) 'Everyday Investor Subjects and Global Financial Change: The Rise of AngloAmerican Mass Investment', in J. M. Hobson and L. Seabrooke (eds), Everyday Politics of The World Economy. Cambridge: Cambridge University Press.

Mann, M. (2003) Incoherent Empire. London: Verso.

Mosley, L. (2003) Global Capital and National Governments. Cambridge: Cambridge University Press.

Reus-Smit, C. (2004) American Power and World Order. Cambridge: Polity. 
Sabel, C. F. (1994) 'Learning by Monitoring: The Institutions of Economic Development', in N. J. Smelser and R. Swedberg (eds), The Handbook of Economic Sociology. Princeton NJ: Princeton University Press, pp. 137-65.

Seabrooke, L. (2001) US Power in International Finance: The Victory of Dividends. Basingstoke: Palgrave Macmillan.

Seabrooke, L. (2004) 'The Economic Taproot of US Imperialism: The Bush Rentier Shift', International Politics, 41 (3), 293-318.

Seabrooke, L. (2006a) The Social Sources of Financial Power: Domestic Legitimacy and International Financial Orders. Ithaca NY: Cornell University Press.

Seabrooke, L. (2006b) The Everyday Social Sources of Economic Crises: From 'Great Frustrations' to 'Great Revelations' in Interwar Britain. Unpublished manuscript, International Center for Business and Politics, Copenhagen Business School.

Seabrooke, L. (2007a) 'Everyday Legitimacy and International Financial Orders: The Social Sources of Imperialism and Hegemony in Global Finance', New Political Economy, 12 (1), forthcoming.

Seabrooke, L. (2007b) 'Why Political Economy Needs Historical Sociology', International Politics, 44 (3), forthcoming.

Seabrooke, L. (2007c) 'Varieties of Economic Constructivism in Political Economy: Uncertain Times Call for Disparate Measures', Review of International Political Economy, 14 (2).

Sharman, J. C. (2006) Havens in a Storm: The Global Struggle for Tax Regulation. Ithaca NY: Cornell University Press.

Sinclair, T. J. (1994) 'Passing Judgement: Credit Rating Processes as Regulatory Mechanisms of Governance in the Emerging World Order', Review of International Political Economy, 1 (1), 133-59.

Stopford, J. M. and Strange, S. (1991) Rival States, Rival Firms: Competition for World Market Shares, with J. S. Henley. Cambridge: Cambridge University Press.

Strange, S. (1986) Casino Capitalism. Oxford: Basil Blackwell.

Strange, S. (1987) 'The Persistent Myth of Lost Hegemony', International Organization, 41 (4), 551-74.

Strange, S. (1988) 'The Future of the American Empire', Journal of International Affairs, 42 (1), 1-17.

Verdier, D. (2002) Moving Money: Banking and Finance in the Industrialized World. Cambridge: Cambridge University Press. 